\title{
Corrosión de las armaduras de acero debida a la carbonatación acelerada de soluciones que simulan la composición de la fase acuosa del hormigón (*)
}

\section{Corrosion behaviour of steel during accelerated carbonation of solutions which simulate the pore concrete solution}

\section{RESUMEN}

A pesar de los numerosos estudios realizados en torno a la carbonatación del hormigón, son muy pocos los datos publicados acerca del mecanismo de despasivación del acero y las velocidades de corrosión implicadas en el proceso de corrosión por carbonatación. Por otra parte, aún no se conoce la composición de la fase acuosa de un hormigón carbonatado.

Cierta erraticidad en los cambios registrados en la velocidad de corrosión del acero durante la carbonatación acelerada de morteros de cemento, puso de manifiesto la necesidad del estudio del proceso en un sistema simplificado que permitiera considerar aisladamente cada uno de los distintos parámetros. A este fin se utilizaron como disoluciones de simulación de la fase acuosa intersticial del hormigón, disoluciones saturadas de $\mathrm{Ca}(\mathrm{OH})_{2}$ con distintas adiciones de $\mathrm{NaOHO}$ $\mathrm{KOH}$.

En el presente trabajo, se han registrado simultáneamente los cambios en el valor del $\mathrm{pH}$ de la disolución, potencial de corrosión y velocidad de corrosión (medida a través de la determinación de la Resistencia de Polarización) de redondos de acero, durante la carbonatación acelerada producida por un flujo constante de $\mathrm{CO}_{2}$ gaseoso y/o aire a través de la disolución.

(*) Presentado al "8. Congreso Internacional de Química do Cemento" Rio de Janeiro, Brasil, 22-27 septiembre 1986.

MATERIALES DE COSTRUCCION, Vol. 37, n.²06, abril/mayo/junio 1987

\section{SUMMARY}

In spite of the numerous studies carried out on carbonation of the concrete, very few data have been published on the mechanism of steel depassivation and the corrosion rates involved in this type of phenomenon. Also some uncertainties remain as to the chemical composition of the pore solution of a carbonated concrete.

Random behaviours related with the changes in the corrosion rate of steel during accelerated carbonation of cement mortars have suggested the need to study the process in a more simple medium which allows the isolation of the different parameters. Thus, saturated $\mathrm{Ca}(\mathrm{OH})_{2}$-base solutions with different additions of $\mathrm{KOH}$ and $\mathrm{NaOH}$ have been used to simulate the real pore concrete solution.

In the present work, simultaneous changes in the $\mathrm{pH}$ value, corrosion potential and corrosion rate (measured by means of the determination of the Polarization Resistance) of steel roads have been monitored during accelerated carbonation produced by a constant flux through the solution of $\mathrm{CO}_{2}$ gas and/or air. 
Las diferencias detectadas en la variación de estas magnitudes en disoluciones con y sin iones $\mathrm{Na}^{\prime}$ y $\mathrm{K}^{\prime}$. pueden ayudar a comprender los diferentes tipos de comportamiento observados en morteros hechos con distintos tipos de cemento. Ya que el $\mathrm{CaCO}_{3}$ es insoluble. las disoluciones que no contienen alcalis se carbonatan más

rápidamente que las que los contienen. Los valores finales de $\mathrm{pH}$ de las soluciones saturadas de $\mathrm{Ca}(\mathrm{OH})$, sin álcalis son siempre próximos a la neutralidad ( $\mathrm{pH}=6-7$ ). sin embargo, las disoluciones que contienen álcalis pueden alcanzar un pH final en torno a 10.4. en el cual se establece un tampón $\mathrm{CO}_{3} / \mathrm{HCO}_{3}$. Sólo cuando pasa un exceso de gas CO. a través de la disolución. los carbonatos de sodio y potasio son transformados totalmente a bicarbonatos y el valor de $\mathrm{pH}$ final se aproxima a valores en torno a la neutralidad.

Estos resultados conducen a una aparente contradición entre los valores finales de $\mathrm{pH}$ de la fase acuosa de hormigones carbonatados naturalmente y aquellos resultados de una carbonatación acelerada.

En lo que se refiere al comportamiento frente a la corrosión. la hipótesis anterior es confirmada usando aire como agente de carbonatación con lo que el proceso de carbonatación se aproxima al natural. El potencial de corrosion de acero aumenta según el valor del $\mathrm{pH}$ disminuye hasta que se alcanza un valor limite y tiene lugar la despasivación. Después la corrosión comienza con una velocidad que depende del valor final del $\mathrm{pH}$ de la disolución y. por tanto. de su contenido en bicarbonatos.
Some clear differences in these variables have been established between solutions with and without $\mathrm{Na}{ }^{\circ}$ and $K$ ions, which may clarify the different corrosion behaviours observed in mortar made with different types of cements. Because $\mathrm{CaCO}$, is insoluble. the solution not containing alkalies are carbonated more quickly than those containing them. Final $\mathrm{pH}$ values in the case of a sat. $\mathrm{Ca}(\mathrm{OH})$, alkali-free solution are always near neutrality (pH-6-7), but solutions containing alkalies may have a final $\mathrm{pH}$ value of about 10.4 where a buffer of $\mathrm{CO}_{3} / \mathrm{HCO}_{3}$ is established. Only when an excess of $\mathrm{CO}_{2}$ gas is passed through the solution, are all sodium and potasium carbonates transformed into bicarbonates and the final $\mathrm{pH}$ value is about neutrality.

These results lead to an apparent contradiction between the final $\mathrm{pH}$ values of real carbonated concretes an those carbonated in an accelerated form.

Concerning to the corrosion behaviour. the previous hypothesis is confirmed using air as carbonating agent. The corrosion potential of steel rises simultaneously with the decrease in $\mathrm{pH}$ value is until a limit is reached and depassivation occurs. After this moment corrosion starts and the corrosion rate is dependent on the final $\mathrm{pH}$ value of the solution and. therefore, its bicarbonate content.

\section{INTRODUCCION}

La carbonatación del hormigón es un tema de creciente preocupación en Europa, donde en numerosas estructuras la superficie del hormigón está directamente expuesta a la acción de la atmósfera y donde las normas permiten espesores de recubrimiento de las armaduras relativamente bajos.

Como es bien conocido, se entiende por "carbonatación" la reacción entre el $\mathrm{CO}_{2}$ atmosférico con la disolución acuosa encerrada en los poros del hormigón y con las fases sólidas de las pastas de cemento. Tal y como distintos autores han establecido (1) (2) la fase final en este proceso consiste en $\mathrm{SiO}_{2}$ amorfa, $\mathrm{Al}(\mathrm{OH})_{3}, \mathrm{CaSO}_{4} .2 \mathrm{H}_{2} \mathrm{O}, \mathrm{CaCO}_{3}$ en distintas variedades polimórficas y $\mathrm{H}_{2} \mathrm{O}$. De este modo, se neutraliza la alcalinidad inicial de la disolución acuosa de los poros del hormigón. Esta neutralización posibilita la corrorión de las armaduras si están presentes un mínimo de humedad y oxígeno (3).

A pesar del gran número de estudios (4) (5) en torno a la carbonatación del hormigón, muy pocos afrontan la cuestión de cómo y en que extensión tiene lugar la corrosión de las armaduras durante la carbonatación. El conocimiento de las velocidades de corrosión de acero permitiría el cálculo de la vida en servicio residual de la estructura.

\section{INTRODUCTION}

The carbonation of concrete is a matter of increasing concern in Europe, where many structures have their concrete surface directly exposed to the action of the atmosphere and the standard allow relatively little depth of cover of reinforcements.

As is already well Known "carbonation" means the reaction between the atmospheric $\mathrm{CO}_{2}$ with the pore concrete solution and with the solid phases of the cement paste. As different authors have stated (1) (2) the final state of this process consists of amorphous $\mathrm{SiO}_{2}$, $\mathrm{Al}(\mathrm{OH})_{3}, \mathrm{CaSO}_{4} .2 \mathrm{H}_{2} \mathrm{O}, \mathrm{CaCO}_{3}$ in different polymorphic varieties and $\mathrm{H}_{2} \mathrm{O}$. Thus, the initial alkaline $\mathrm{pH}$ in the pore concrete solution is neutralized. This neutralization allows the corrosion of reinforcements if a minimum of moisture and oxygen are present (3).

But in spite of numerous studies (4) (5) on the carbonation of concrete, very few of them have addressed the question of how and to what extent the corrosion of reinforcements occurs during carbonation. The ascertaining of the corrosion rates of the steel would permit the calculation of the residual service life of the structure. 
La única explicación común en hormigón carbonatado es que el valor del $\mathrm{pH}$ desciende y que las armaduras se corroen. Tan solo los autores que han estudiado el efecto de la presencia de grietas y han medido la disminución de diámetro de las barras debido a la carbonatación en la región de la grieta (6), dan un valor medio y aprosimado de la velocidad de corrosión en estos puntos.

Hace algunos años se inició un proyecto de investigación en nuestro Instituto para estudiar esta laguna de conocimiento y ya han sido publicados algunos resultados en este campo (3) (7).El trabajo experimental trata fundamentalmente del estudio de los parámetros de la corrosión de las armaduras embebidas en hormigon o mortero carbonatado o sumergidas en disoluciones carbonatadas que reproducen la composición de la fase acuosa encerrada en los poros del hormigón.

En estos experimentos se utilizó un sistema de carbonatación acelerado con el empleo de $\mathrm{CO}_{2}$ gas, puro. Este método produce una saturación en $\mathrm{CO}_{2}$ de la disolución o de la cámara de carbonatación y puede conducir a fenómenos diferentes a los que tienen lugar cuando la carbonatación se produce naturalmente (el contenido en $\mathrm{CO}_{2}$ de la atmósfera es de 0,03\% aproximadamente). Esta circunstacia es analizada en el presente artículo y se tendrá en cuenta en el futuro trabajo experimental.

En este trabajo se ponen de manifiesto cambios de la composición química de soluciones de simulación de la fase acuosa del hormigón durante su carbonatación acelerada o natural (por el aire), presentándose simultáneamente las variaciones en el potencial y en la velocidad de corrosión de las armaduras. Los resultados confirman las hipótesis ya publicadas (3) (7) y permiten una mayor comprensión del fenómeno.

\section{PARTE EXPERIMENTAL}

\section{Materiales y Disoluciones}

Se utilizaron barras de acero corrugado de $6 \mathrm{~mm}$ de diámetro y $8 \mathrm{~cm}$ de longitud. La interfase aire-disolución y el extremo inferior del redondo se cubrieron con cinta adhesiva anticorrosión. De este modo, la superficie expuesta al ataque fue de $5 \mathrm{~cm}^{2}$ aproximadamente.

La célula de corrosión utilizada es de polietileno. y se muestra en la fig. 1.
The only common statement in carbonated concrete is that $\mathrm{pH}$ value decreases and the reinforcements corrode. Only authors who have studied the effect of cracks and have measured the decrease in diameter of the bars due to carbonation in the region of cracks (6) give an approximate and medium value of the corrosion rate at these points.

Some years ago a research project was initiated in our Institute to study this gap in Knowledge and some results have already been published (3) (7). The experimental work mainly dealt with the study of the corrosion parameters of reinforcements embedded in hardened carbonated mortar or concrete and immersed in carbonated solutions that reproduce the composition of the pore concrete solution.

But the system used for carbonating in these experiments was one accelerated by pure $\mathrm{CO}_{2}$ in the solution or in the carbonation chamber and may lead to different phenomena from those which occurs when carbonation is produced naturally (the proportion of $\mathrm{CO}_{2}$ in the atmosphere is about $0.03 \%$ ). This point is analyzed in the present paper and is taken into account in the future experimental work.

This paper sets out changes in the chemical composition of like-pore concrete solutions during accelerated and natural carbonation (by air) and also the results of simultaneous changes of corrosion potentials and corrosion rates of reinforcements. The results confirm the previously published hypothesis (3) (7) giving a new insight into the phenomenon.

\section{EXPERIENTAL}

\section{Materials and solutions}

Corrugated steel bars $6 \mathrm{~mm}$ in diameter and $8 \mathrm{~cm}$ in length were used. The air/solution interphase and the lower end of the steel were covered with and adhesive tape. The surface exposed to attack was about $5 \mathrm{~cm}^{2}$.

The corrosion cell is a polythylene bottle shown in figure 1. 


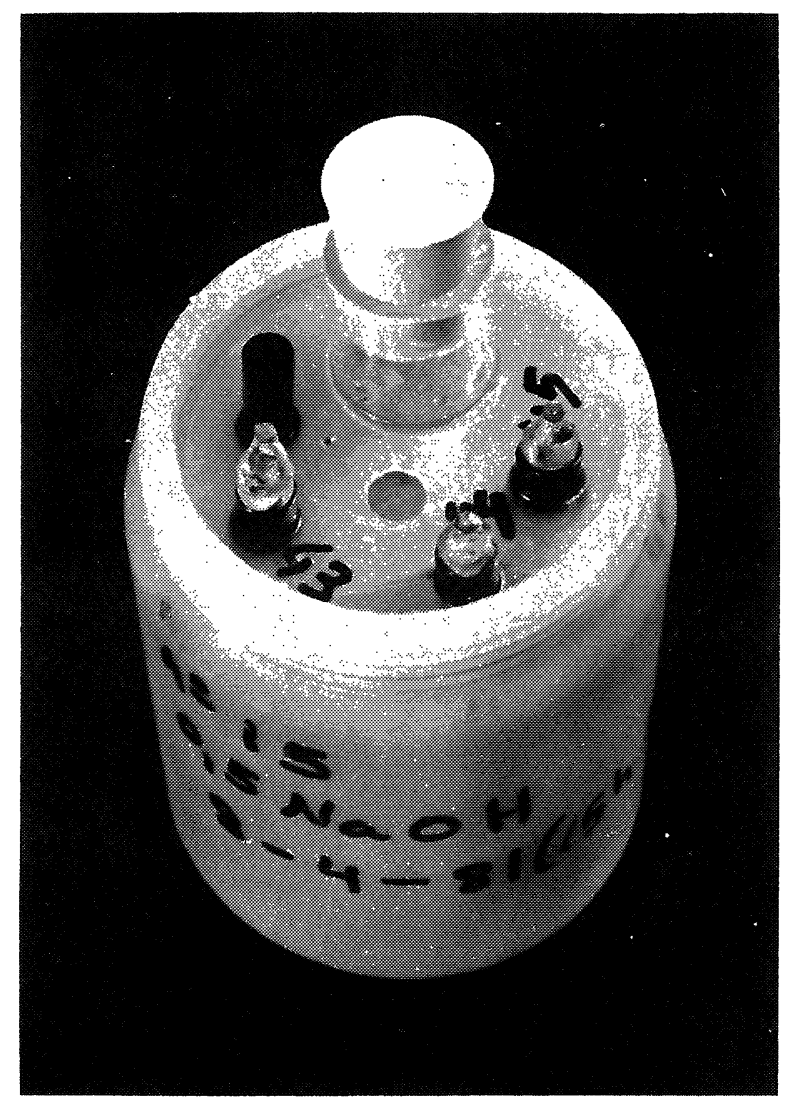

Fig. 1.-Corrosion cell of polyethylene.

Las disoluciones ensayadas, preparadas con reactivos calidad de análisis, fueron las siguientes:

Disolución A.-Disolución saturada de $\mathrm{Ca}(\mathrm{OH})_{2}(8 \mathrm{~g} / \mathrm{l}) \ldots \ldots \ldots \ldots \ldots \quad \mathrm{pH}=12,6$

Disolución B.-Disolución saturada $\mathrm{Ca}(\mathrm{OH})_{2}+0,1 \mathrm{M} \mathrm{NaOH}+0,1 \mathrm{M}$

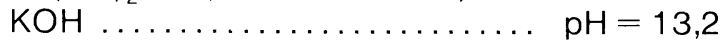

Disolución C.-Disolución saturada de $\mathrm{Ca}(\mathrm{OH})_{2}+0,5 \mathrm{M} \mathrm{HaOH} \ldots . \quad \mathrm{pH}=13,5$

Disolución D.-Disolución saturada de $\mathrm{Ca}(\mathrm{OH})_{2}+0,1 \mathrm{M} \mathrm{NaNO}_{2} \ldots . \quad \mathrm{pH}=12,8$

Disolución E.-Disolución saturada de $\mathrm{Ca}(\mathrm{OH})_{2}+0,1 \mathrm{M} \mathrm{NaOH}+0,1 \mathrm{M}$ $\mathrm{KOH}+0,1 \mathrm{M} \mathrm{NaNO}_{2} \ldots \ldots \ldots . \quad \mathrm{pH}=13,3$

Una vez finalizado el período de carbonatación se analizó el contenido en $\mathrm{CO}_{3}$ y $\mathrm{HCO}_{3}$ de alguna de las disoluciones ensayadas por el método tradicional de valoración con $\mathrm{HCl}$.

\section{Método experimental}

La carbonatación se realizó mediante burbujeo lento de $\mathrm{CO}_{2}$ gas, puro o aire a través de la disolución. Durante el tiempo de burbujeo de los
The following solutions were tested. They were prepared with reagents in analytical grade:

Solution A.-Saturated solution of

$\mathrm{Ca}(\mathrm{OH})_{2}(8 \mathrm{~g} / \mathrm{l}) \ldots \ldots \ldots \ldots \ldots \ldots \quad \mathrm{pH}=12.6$

Solution B.-Saturated solution of $\mathrm{Ca}(\mathrm{OH})_{2}+0.1 \mathrm{M} \mathrm{NaOH}+0.1 \mathrm{M}$

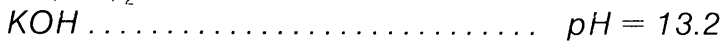

Solution C.-Saturated solution of $\mathrm{Ca}(\mathrm{OH})_{2}+0.5 \mathrm{M} \mathrm{NaOH} \ldots \ldots \ldots p \mathrm{pH}=13.5$

Solution D.-Saturated solution of $\mathrm{Ca}(\mathrm{OH})_{2}+0.1 \mathrm{M} \mathrm{NaNO}_{2} \ldots \ldots . p \mathrm{H}=12.8$

Solution E.-Saturated solution of $\mathrm{Ca}(\mathrm{OH})_{2}+0.1 \mathrm{M} \mathrm{NaOH}+0.1 \mathrm{M}$ $\mathrm{KOH}+0.1 \mathrm{M} \mathrm{NaNO}_{2} \ldots \ldots \ldots \ldots \quad p H=13.3$

After the completion of the carbonation period the proportion of $\mathrm{CO}_{3}$ and $\mathrm{HCO}_{3}$ were analyzed in some solutions by the traditional method of titration by $\mathrm{HCl}$.

\section{Experiments}

The carbonation was produced by slowly bubbling either pure $\mathrm{CO}_{2}$ gas or air through the solution. During the flux of the gases the

MATERIALES DE COSTRUCCION, Vol. 37, n. 206, abril/mayo/junio 1987 
gases, se registró continuamente el valor de $\mathrm{pH}$ medido con un $\mathrm{pH}$-metro y un electrodo combinado de rango 0-14. El electrodo fué calibrado de vez en cuando con dos tampones de $\mathrm{pH}=7$ y $\mathrm{pH}=12-13$.

La concentración del $\mathrm{O}_{2}$ en la disolución fué medida con un electrodo selectivo ORION de oxígeno. Esta también fué registrada continuamente.

El flujo de los gases se mantuvo 24 horas; despues de este tiempo las células se colocaron a temperatura ambiente $\left(21 \pm 1^{\circ} \mathrm{C}\right)$ por otros 5 a 8 dias.

El potencial de corrosión, $\mathrm{E}_{\text {corr }}$, medido a través de un potenciostato fué registrado, así mismo, simultánea y continuamente. Sin embargo, debido a los cambios abruptos fruto del burbujeo de los gases, la velocidad de corrosión sólo se midió inmediatamente antes y al final del proceso de carbonatación. También se realizaron medidas diarias tras la carbonatación de las disoluciones.

La velocidad de corrosión se calculó a partir de la medida de la Resistencia de Polarización utilizando la fórmula del método de Stern (18):

$$
\mathrm{I}_{\mathrm{corr}}=\mathrm{B}(\triangle \mathrm{I} / \triangle \mathrm{E})=\mathrm{B} / R_{\mathrm{p}}
$$

Las medidas de $R_{0}=(\triangle E / \triangle I) \triangle E \rightarrow 0$ fueron realizadas con un potenciostato. Se utilizó un valor de B de 26 y $52 \mathrm{mV}$ para el acero en estado activo y pasivo respectivamente (3).

\section{RESULTADOS}

En trabajos previos (7) se publicaron los resultados de la variación del valor del $\mathrm{pH}$, potencial y velocidad de corrosión durante y posteriormente a la carbonatación acelerada con $\mathrm{CO}_{2}$ gas, puro, de la disolución $\mathrm{A}$ [disolución saturada de $\mathrm{Ca}(\mathrm{OH})_{2}$ ] y $\mathrm{B}$ [disolución saturada de $\mathrm{Ca}(\mathrm{OH})_{2}+0,1 \mathrm{M}$ $\mathrm{NaOH}+0,1 \mathrm{M} \mathrm{KOH}]$. A fin de facilitar una comparación posterior, estos resultados se reproducen en las figuras 2 y 3 .

Una de las cuestiones que debe ser clarificada en estos ensayos concierne a los bruscos cambios registrados en el $E_{\text {corr }}$ y la $I_{\text {corr }}$ durante la carbonatación acelerada. Estos cambios fueron atribuidos al descenso del $\mathrm{pH}$ y a la consiguiente despasivación del acero, pero podrian también ser debidos a la desaireación de la disolución provocada por el flujo de $\mathrm{CO}_{2}$ gas, puro. $p H$-value was continously recorded with a $\mathrm{pH}$-meter and a combined electrode of the $\mathrm{pH}$ range 0-14. The electrode was calibrated from time to time with two buffers of $\mathrm{pH}=7$ and $p H=12 \cdot 13$.

The concentration of $\mathrm{O}_{2}$ in the solutions was measured by a special ORION electrode of oxygen. It was also monitored continously.

The flux of gases lasts up to $24 \mathrm{~h}$, after which time the cell is held at room temperature $\left(21 \pm 1^{\circ} \mathrm{C}\right)$ for a further 5-8 days.

The corrosion potential, $E_{\text {corr }}$, was also simultaneously and continously monitored through a potentiostat. However, given the abrupt changes during the flux of gases the corrosion rate was only measured just prior to and on completion of the test. It was also measured every day afther the solution had been carbonated.

The corrosion rate is calculated from the Polarization Resistance, $R_{p}$, determinations by the Stern's et al method (8) through the formula:

$$
I_{\text {corr }}=B(\triangle I / \triangle E)=B / R_{p}
$$

The $R_{p}=(\triangle E / \triangle I) \triangle E \rightarrow 0$ measurements were taken with a potentiostat. Values of the constant $B$ of 26 and $52 \mathrm{mV}$ were used for steel in the active and passive states respectively, as it has been described (3).

\section{RESULTS}

The results of the variations of $\mathrm{pH}$-values, corrosion potential and corrosion intensity during and after accelerated carbonation by pure $\mathrm{CO}_{2}$ gas of the solution A (satured solution of $\mathrm{Ca}(\mathrm{OH})_{2}$ and $B$ (satureted solution of $\mathrm{Ca}(\mathrm{OH})_{2}+0.1 \mathrm{M} \mathrm{NaOH}+0.1 \mathrm{M} \mathrm{KOH}$ ) were published in a previous paper (7). For the purpose of comparison the results are reproduced in figure 2 and 3.

One of the points to be clarified in these tests concerns the dramatic changes measured in the $E_{\text {corr }}$ and $I_{\text {corr }}$ values during the accelerated carbonation. These changes were attributed to the lowering of the $\mathrm{pH}$ and therefore to the depassivation of the steel, but they may also be due to the deaeration of the solution provoked by the flux of the pure $\mathrm{CO}_{2}$ gas. 

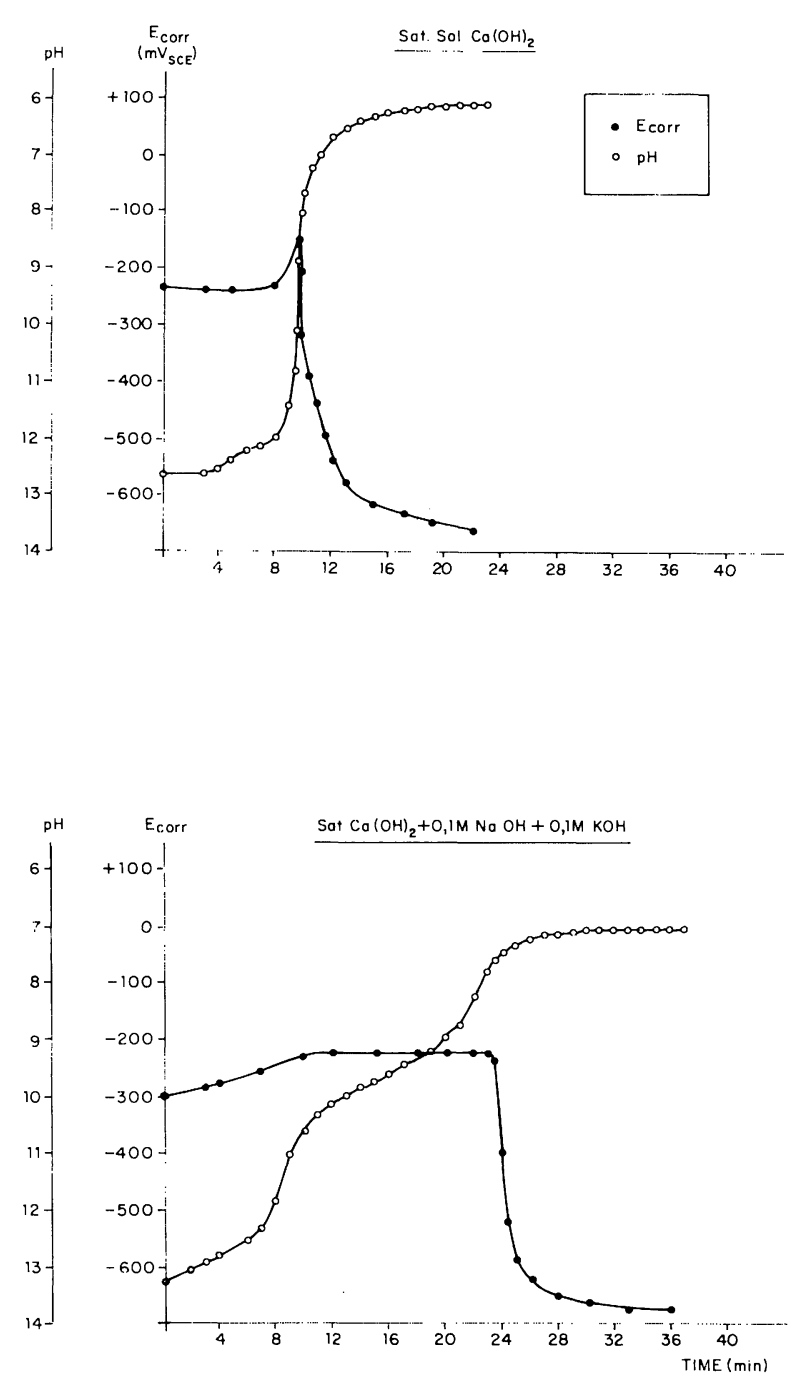

Fig. 2.-Evolution of $E_{\text {corr }}$ and $\mathrm{pH}$ during carbonation of Sat. Sol. $\mathrm{Ca}(\mathrm{OH})_{2}$ with and without $\mathrm{Na}^{+}$and $\mathrm{K}^{+}$ions (7).

Por lo tanto se llevó a cabo un experimento previo en el que se midió la evolución de la concentración de oxígeno durante el proceso de carbonatación, comparándose los valores con aquellos de una simple desaireación obtenida con corriente de $\mathrm{N}_{2}$. Los resultados del descenso de la concentración de $\mathrm{O}_{2}$ durante el paso de corriente de $\mathrm{CO}_{2}$ o de $\mathrm{N}_{2}$ a través de una disolución tipo A se muestran en la figura 4. La desaireación debida a la corriente de $\mathrm{CO}_{2}$ es más profunda que en corriente de $\mathrm{N}_{2}$.

El ensayo de la carbonatación de la solución tipo A [disolución saturada de $\mathrm{Ca}(\mathrm{OH})_{2}$ ] fué posteriormente repetido usando una corriente de aire (para lo que se empleó una pequeña bomba de aire) a fin de producir carbonatación
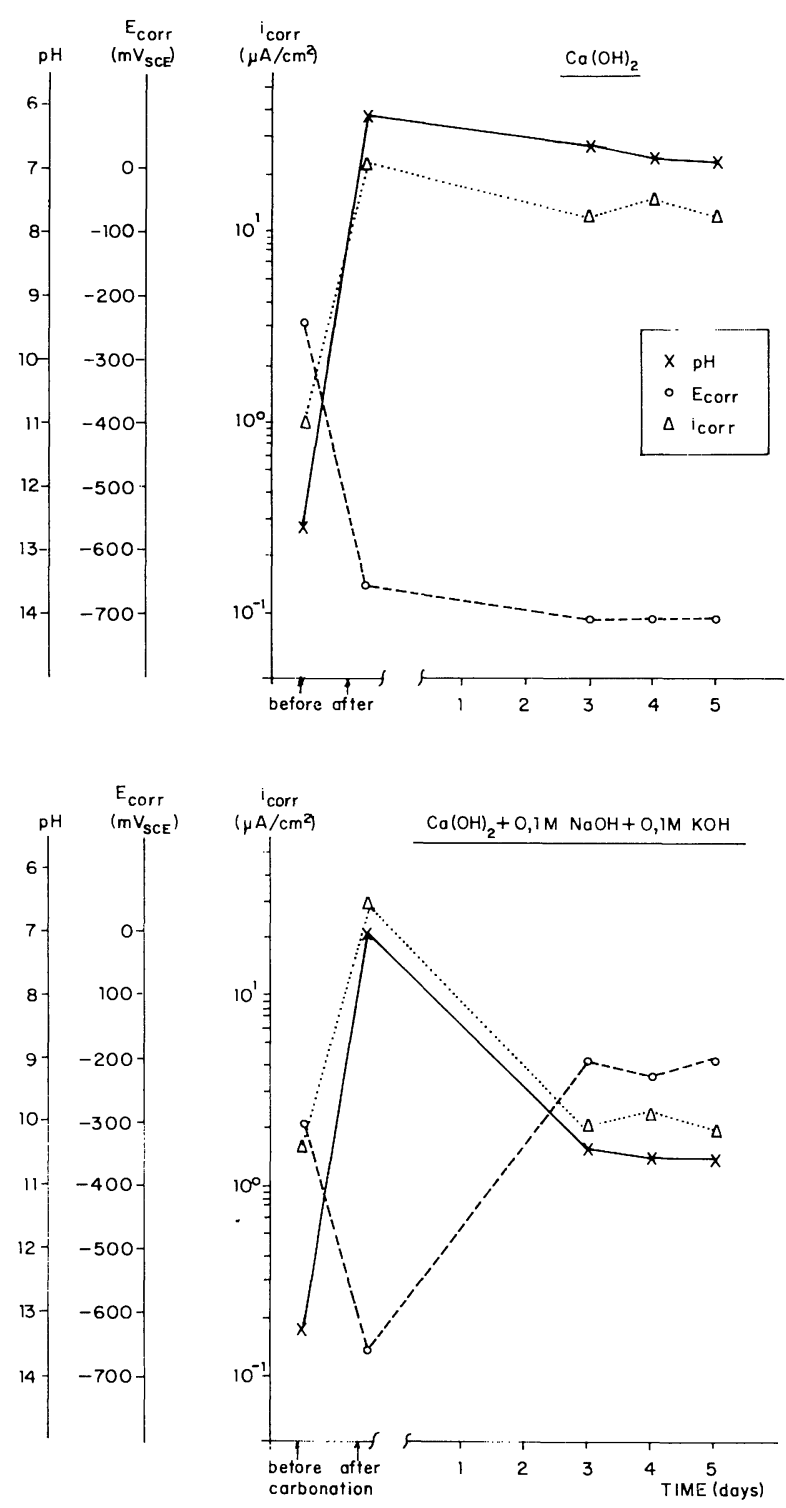

Fig. 3.-Values $i_{\text {corr }}$ until 5 days after carbonation of the same solution of previous figure (7).

Therefore a previous experiment was carried out consisting of measuring the concentration of oxygen during the carbonation experiment compared with a simple deaeration by flux of $\mathrm{N}_{2}$. The results of the decrease in $\mathrm{O}_{2}$ concentration during the pass either of $\mathrm{CO}_{2}$ flux or of $\mathrm{N}_{2}$ flux through a type $A$ solution are shown in figure 4 . The deaeration due to the flux of $\mathrm{CO}_{2}$ is deeper than with $\mathrm{N}_{2}$.

The test of carbonation of the type A solution [saturated solution of $\mathrm{Ca}(\mathrm{OH})_{2}$ only] was subsequently repeated but using a flux of air (using a small air pump) to produce carbonation and avoid deaeration. The

MATERIALES DE COSTRUCCION, Vol. 37, n.o 206, abril/mayo/junio 1987 

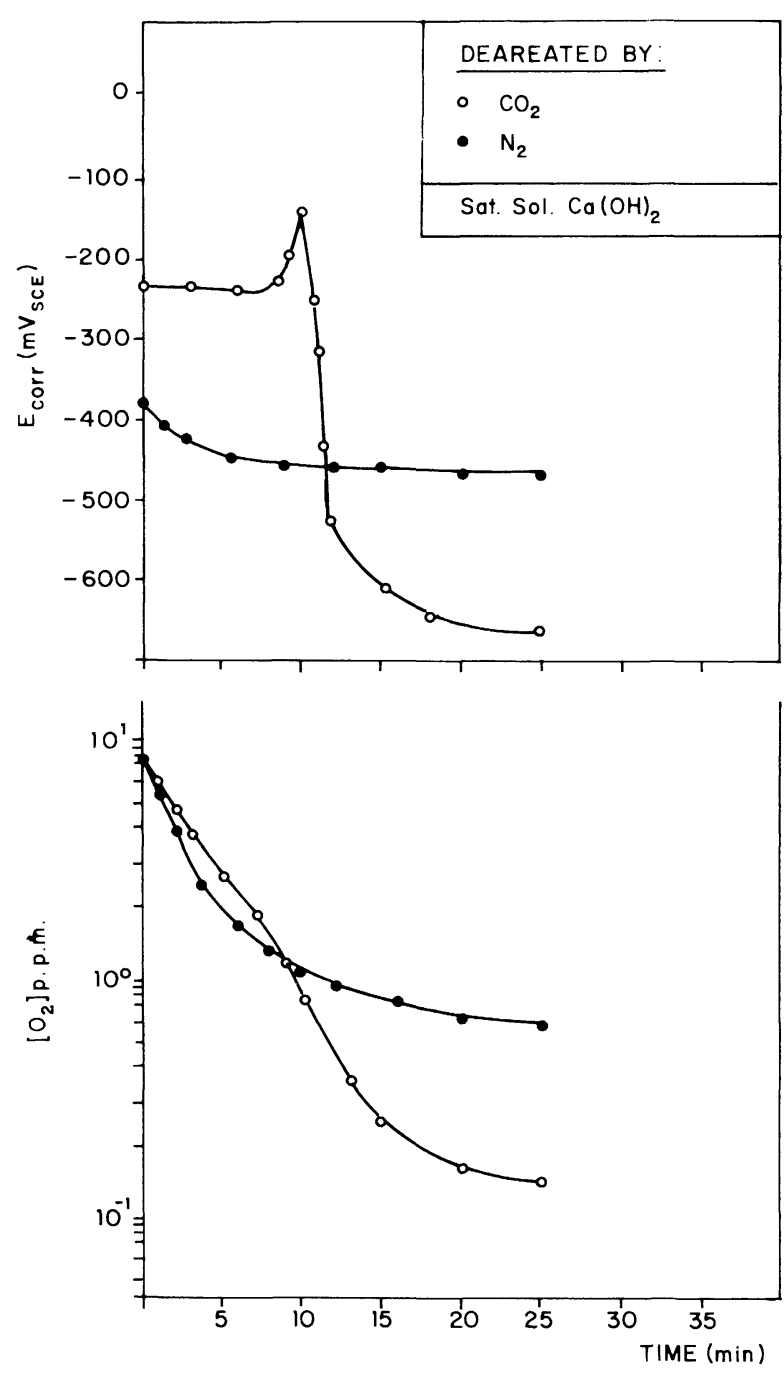

Fig. 4.-Decrease in $\mathrm{O}_{2}$ concentration in a saturated solution of $\mathrm{Ca}(\mathrm{OH})_{2}$ deareated by flux of $\mathrm{CO}_{2}$ and of $\mathrm{N}_{2}$

y evitar la desaireación. La evolución del valor de $\mathrm{pH}, \mathrm{E}_{\text {corr }}, \mathrm{I}_{\text {corr }}$ y concentración de $\mathrm{O}_{2}$ se presenta en la figura 5. Los cambios abruptos se producen ahora aproximadamente a las 24 horas del comienzo de los ensayos y no depués de unos pocos minutos (como ocurría en corriente de $\mathrm{CO}_{2}$ puro), pero la evolución de los cambios es idéntica al de las figuras 2 y 3. La desaireación provocada por el $\mathrm{CO}_{2}$ puro sólo influye en el valor final del potencial de corrosión y en el valor absoluto de la intensidad de corrosión. Por lo tanto, estos resultados confirman la hipótesis previa (3) (7) en la que se atribuye el cambio brusco al descenso del valor de $\mathrm{pH}$ y a la despasivación del acero.

También se ensayó una disolución con una concentración de álcali superior (transcurridos
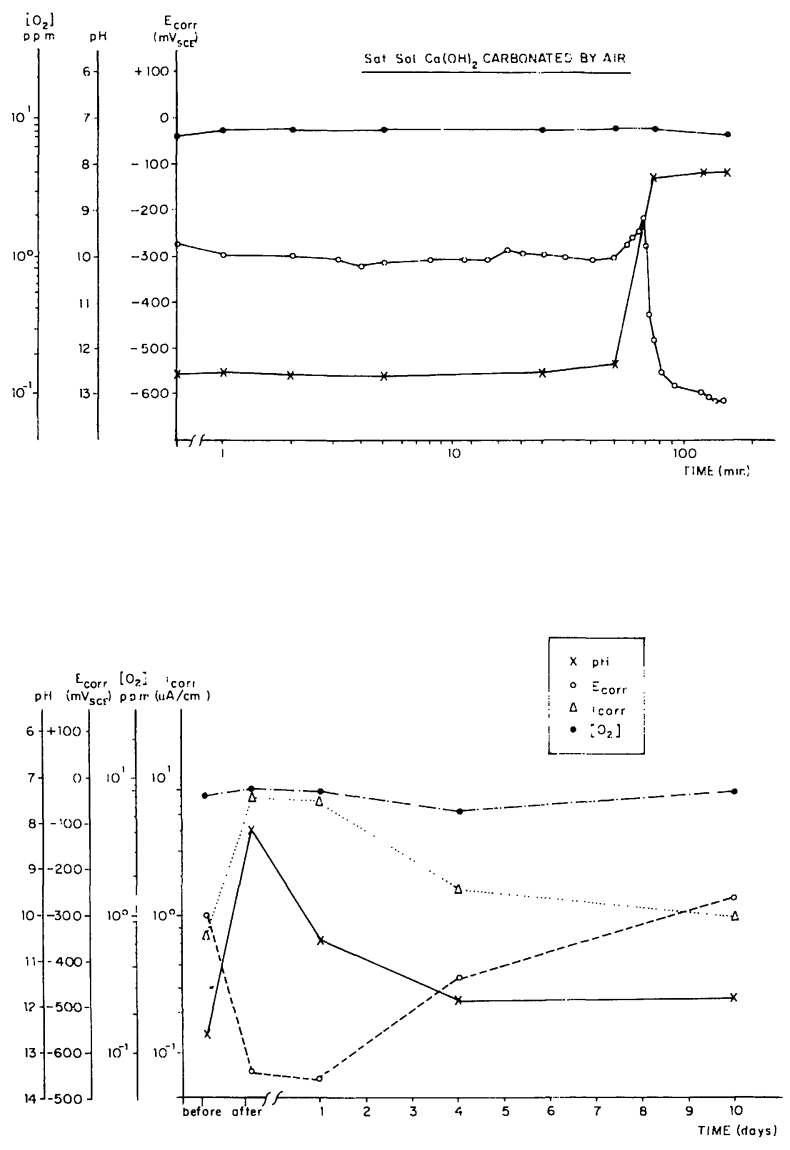

Fig. 5.-Evolution of the $\mathrm{pH}$ values. $E_{\text {corr }}, i_{\text {corr }}$ and $\mathrm{O}_{2}$ concentration of a saturated solution of $\mathrm{Ca}(\mathrm{OH})_{2}$ carbonated by air during the carbonation process and for a further 10 days.

evolution of the $\mathrm{pH}$ value, $E_{\text {corr }}, I_{\text {corr }}$ and $\mathrm{O}_{2}$ concentration is presented in figure 5 . The abrupt changes are now produced about $24 \mathrm{~h}$ after the beginning of the test and not after few minutes (as with pure $\mathrm{CO}_{2}$ ), but the trend of the changes is identical to those shown in figures 2 and 3 . The deaeration provoked by the pure $\mathrm{CO}_{2}$ only influences the final value of the corrosion potential and the absolute value of the corrosion intensity. Therefore, this confirms the previous hypothesis (3) (7) attributing the dramatic change to the lowering of the $\mathrm{pH}$ value and the depassivation of the steel.

A solution with a higher concentration of alkali was also tested (after some days the $\mathrm{pH}$ of the 


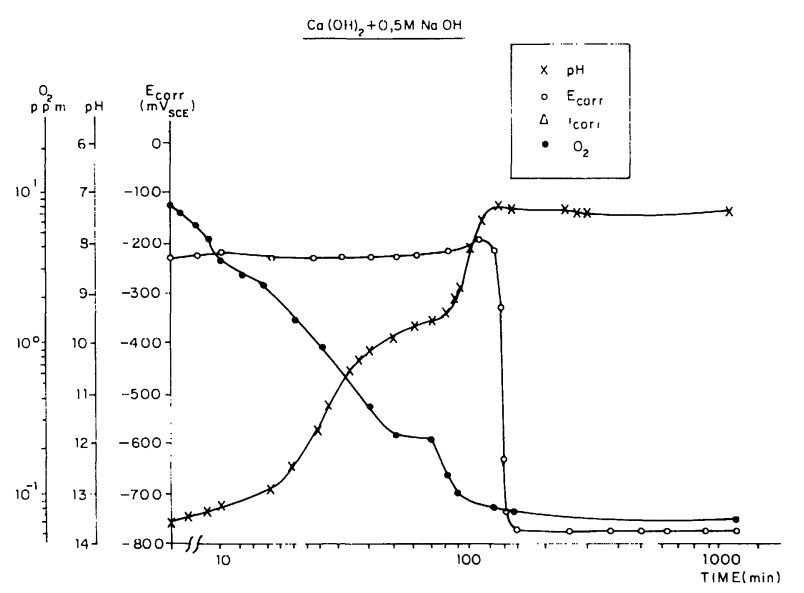

Fig. 6.-Evolution of the $\mathrm{pH}$ value, $\mathrm{E}_{\text {corr }}$ and $\mathrm{O}_{2}$ proportion of a sat. sol. of $\mathrm{Ca}(\mathrm{OH})_{2}$ plus $0.5 \mathrm{M} \mathrm{NaOH}$ during carbonation.
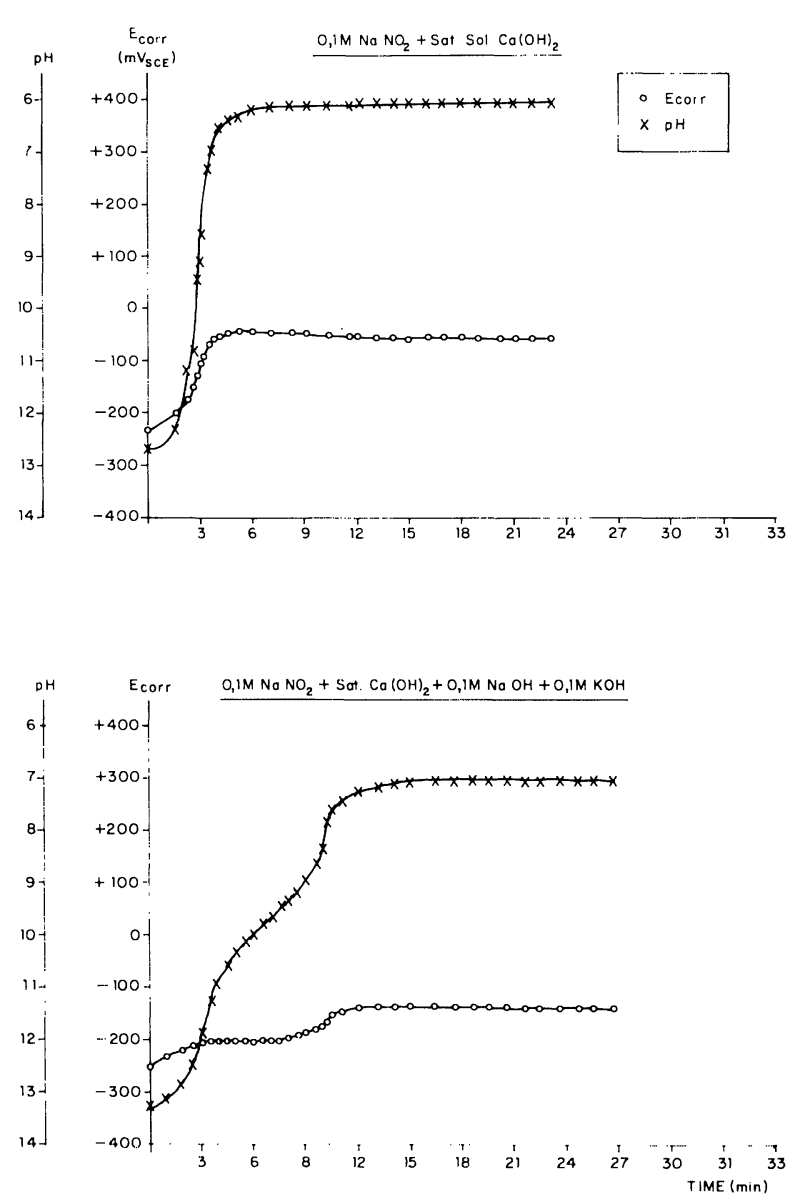

Fig. 7.-Evolution of the some variables and solutions presented in figure 2 but with the addition of $0.1 \mathrm{M}$ $\mathrm{NaNO}_{2}$.

12
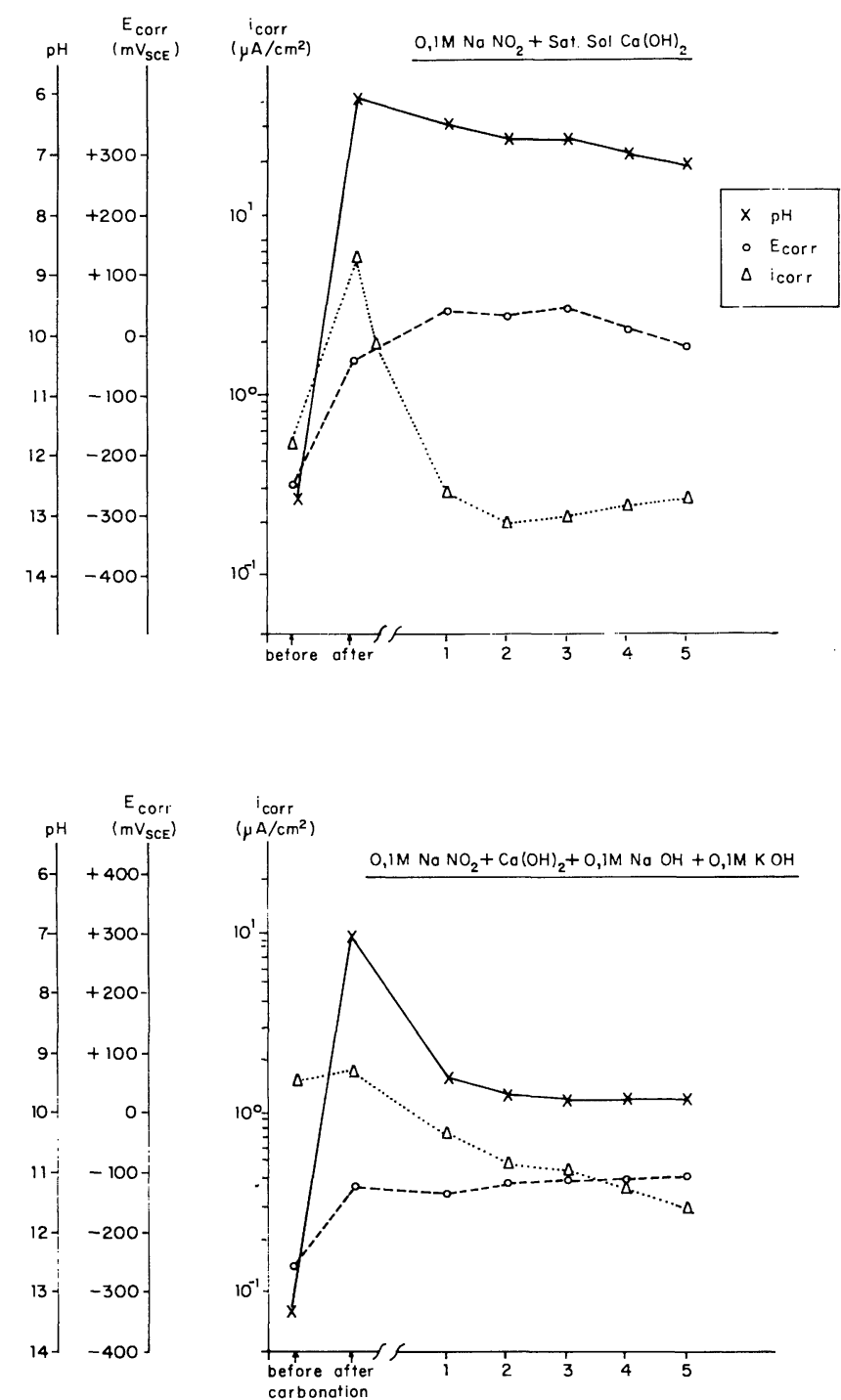

Fig. 8.-Evolution of the same variable and solutions presented in figure 3 but with the addition of $0.1 \mathrm{M}$ $\mathrm{NaNO}_{2}$.

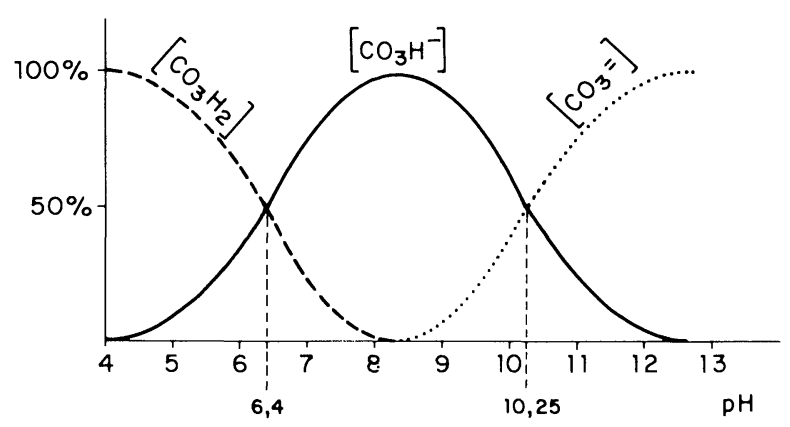

Fig. 9.- Variation with the $\mathrm{pH}$ of the relative concentrations of $\mathrm{CO}_{3}, \mathrm{HCO}_{3}$ and $\mathrm{H}_{2} \mathrm{CO}_{3}$.

MATERIALES DE COSTRUCCION. Vol. 37, n.²06, abril/mayo/junio 1987 
algunos días el pH de la disolución acuosa de los poros del hormigón es normalmente superior a 13,5). La figura 6 muestra la evolución del valor de $\mathrm{pH}, \mathrm{E}_{\text {corr }}, \mathrm{I}_{\text {corr }} \mathrm{y}$ concentración de $\mathrm{O}_{2}$ de una disolución tipo $\mathrm{C}$ [disolución saturada de $\mathrm{Ca}(\mathrm{OH})_{2}+0,5 \mathrm{M}$ $\mathrm{NaOH}$ ] carbonatada por corriente de $\mathrm{CO}_{2}$ puro. La evolución del comportamiento de cada una de las variables es idéntico al de las disoluciones con contenido en álcalis menor y difiere del de la disolución que sólo contiene $\mathrm{Ca}^{2+}$. De nuevo un efecto tampón se produce en $\mathrm{pH} \simeq 10,5$ y los cambios son menos abruptos que cuando los iones $\mathrm{Na}^{+}$y $\mathrm{K}^{+}$no están presentes. Los valores de $\mathrm{pH}$ finales son más alcalinos.

Por último, las figuras 7 y 8 representan la evolución de las mismas variables pero cuando $\mathrm{NaNO}_{2}$ es adicionado con un inhibidor de corrosión. En este caso debe resaltarse que el potencial de corrosión no cambia bruscamente y que la intensidad de corrosión aumenta sólo ligeramente debido al efecto inhibidor del $\mathrm{NO}_{2}^{-}$(oxidante y anódico en este caso).

\section{DISCUSION}

Antes de seguir adelante, debe señalarse que las disoluciones no reproducen la situación real de las armaduras embebidas en hormigón debido a las diferentes propiedades físicas (resistividad eléctrica, la capa sólida de $\mathrm{Ca}(\mathrm{OH})_{2}$ precipitada en la superficie del acero, la geometría de los poros, etc.) y a la evolución con el tiempo de la composición de la fase acuosa encerrada en los poros del hormigón. Sin embargo, constituyen el único método aproximado de estudio aislado de las viables a considerar. En la presente investigación el trabajo en disolución ha contribuido a aclarar distintos aspectos de la corrosión del acero en hormigón carbonatado, aunque no es recomendable una extrapolación directa sin una cuidadosa revisión de todos los errores que esta extrapolación puede introducir y sin una comparación con experimentos paralelos en hormigón (7).

\section{Carbonatación de las disoluciones}

Cuando se burbujea $\mathrm{CO}_{2}$ puro o aire o ambos a través de una disolución saturada de $\mathrm{Ca}(\mathrm{OH})_{2}$, precipita $\mathrm{CaCO}_{3}$ debido a su baja solubilidad y se forma agua. El $\mathrm{pH}$ final depende de la presión parcial del $\mathrm{CO}_{2}$ en la atmósfera cuando se detiene la corriente de gases. $\mathrm{CO}_{2}$ disuelto y $\mathrm{Ca}\left(\mathrm{HCO}_{3}\right)_{2}$ son las sustancias presentes inmediatamente después de cesar el burbujeo ya que, debido a la alta pure concrete solution is usually above 13.5). Figure 6 shows the evolution of $\mathrm{pH}$ value, $E_{\text {corr }}$, $I_{\text {corr }}$ and $\mathrm{O}_{2}$ concentration of type $C$ solution [saturated solution of $\mathrm{Ca}(\mathrm{OH})_{2}+0.5 \mathrm{M} \mathrm{NaOH}$ ] carbonated now by a flux of pure $\mathrm{CO}_{2}$. The trend of the changes in every variable is identical to that of solution with a lower alkaline concentration and different the solution containing only $\mathrm{Ca}^{2+}$. Again a similar buffer effect is produced of about $\mathrm{pH} \simeq 10.5$ and the changes are less abrupt than when $\mathrm{Na}^{+}$and $\mathrm{K}^{+}$ are absent. The final $\mathrm{pH}$ values are more alkaline.

Finally, figures 7 and 8 also present the evolution of the same variables but when $\mathrm{NaNO}_{2}$ is added as a corrosion inhibitor admixture. In this case it must be pointed out that the corrosion potential does not dramatically change and the corrosion intensity increase very little, because of the inhibitor (oxydant and anodic in this case) effect of $\mathrm{NO}_{2}^{-}$. Also the $i_{\text {corr }}$ increases less and the final values are smaller than when $\mathrm{NaNO}_{2}$ absent.

\section{DISCUSSION}

Before continuing, it must be pointed out that solutions do not reproduce the real situation of the bars embedded in concrete because of the differences in the physical parameters (electrical resistivity, the solid layer of $\mathrm{Ca}(\mathrm{OH})_{2}$ precipitated on the surface of the steel, pore geometry, etc.) and the constant evolution of the pore concrete solution. However, they occasionally constitute the only method by which to make an approach and to study isolated variables. In the present experiments the work in solution has clarified many points related with steel corrosion in carbonated concrete, but a simple and direct extrapolation is not recomended without a careful review of all the errors that this extrapolation may introduce and without a comparison with parallel experiments in hardened concrete (7).

\section{Carbonation of the solutions}

When pure $\mathrm{CO}_{2}$ or air or the two gases together are bubbled into a saturated solution of $\mathrm{Ca}(\mathrm{OH})_{2}, \mathrm{CaCO}_{3}$, precipitates owing to its extremely low solubility, and water are formed. The final $\mathrm{pH}$ value would depend on the partial pressure of the $\mathrm{CO}_{2}$ in the atmosphere, when the flux of the gases is stoped. Dissolved $\mathrm{CO}_{2}$ and $\mathrm{Ca}\left(\mathrm{HCO}_{3}\right)_{2}$ are the substances present just after stopping bubbling because, due to the 
concentración de $\mathrm{CO}_{2}$, los carbonatos son redisueltos como bicarbonatos:

$$
\mathrm{CaCO}_{3}+\mathrm{CO}_{2}+\mathrm{H}_{2} \mathrm{O} \rightarrow \mathrm{Ca}\left(\mathrm{HCO}_{3}\right)_{2}
$$

sin embargo, la disolución que contiene iones $\mathrm{Na}^{+}$y $\mathrm{K}^{+}$se comporta de modo distinto ya que $\mathrm{Na}_{2} \mathrm{CO}_{3}$ y $\mathrm{K}_{2} \mathrm{CO}_{3}$ son solubles y pueden permanecer como especies iónicas en disolución. En este caso, la carbonatación produce un cambio menos abrupto de $\mathrm{pH}$ y, a pasar de que el valor del $\mathrm{pH}$ final, justo después de parar el flujo de $\mathrm{CO}_{2}$, es también próximo a la neutralidad (solo bicarbonatos y $\mathrm{CO}_{2}$ disuelto están presentes), en virtud del conocido equilibrio representado en la figura 9, el $\mathrm{pH}$ evoluciona expontáneamente hacia un valor en torno a 10,4 , que es el del tampón carbonato-bicarbonato (9).

Una simple extrapolación de estos resultados al comportamiento real conducirá a concluir que una disolución alcalina que contenga iones $\mathrm{Na}^{+}$y K', completamente carbonatada, presentaría un valor de $\mathrm{pH}$ en torno a $10,4, \mathrm{pH}$ al cual la fenolftaleína adquiriría un color rojo púrpura claro. Todos los cementos tienen álcalis en mayor o menor proporción y, sin embargo, la experiencia muestra que en todos los hormigones carbonatados la fenolftaleína (se produce el viraje entre $\mathrm{pH}=8 \mathrm{y} \mathrm{pH}=9,5$ ) es incolora, esto es, el pH es inferior a 8 . Por lo tanto, o bien o el $\mathrm{Na}^{+} \mathrm{o}$ el $\mathrm{K}^{+}$permanecen siempre como bicarbonatos lo -cual es imposible a la presión parcial de $\mathrm{CO}_{2}$ usual en la atmósfera-, o bien estos iones "desaparecen" de la disolución. Puede pensarse que los iones $\mathrm{Na}^{+}$y $\mathrm{K}^{+}$son consumidos por reacción con sílice amorfa (reacción puzolánica) (10) producida por la acción del $\mathrm{CO}_{2}$ con los silicatos (2) y, en consecuencia, la composición final de la fase acuosa de los poros del hormigón sería agua con $\mathrm{CO}_{2}$ disuelto. Los bicarbonatos estarían presentes sólo si la presión parcial de $\mathrm{CO}_{2}$ es suficientemente elevada.

La interpretación aquí dada del proceso de carbonatación acelerada en base al equilibrio $\mathrm{CO}_{3}=/ \mathrm{HCO}_{3}^{-}$y los valores de $\mathrm{pH}$ implicados es bien conocida en lo que respecta a aguas naturales y potables e incluso el efecto corrosivo de estas aguas en el propio hormigón. Sin embargo, los autores no la han encontrado recogida en la literatura, excepto (11) (12) y sí la "sorpresa" que manifiesta Verbeck (13) cuando considera "el efecto de la concentración de hidróxido alcalino en los valores de $\mathrm{pH}$ de equilibrio a distintas presiones de $\mathrm{CO}_{2}$. El cálculo muestra que en una fase líquida que contenga $1 \mathrm{~N}$ de $\mathrm{KOH}$ en contacto con $\mathrm{CO}_{2}$ a la presión del aire natural el equilibrio se produciria a un $\mathrm{pH}$ en torno a 10,5 . Este hecho representa una situación high concentration of $\mathrm{CO}_{2}$, carbonates are redisolved as bicarbonates:

$$
\mathrm{CaCO}_{3}+\mathrm{CO}_{2}+\mathrm{H}_{2} \mathrm{O} \rightarrow \mathrm{Ca}\left(\mathrm{HCO}_{3}\right)_{2}
$$

But the solution containing $\mathrm{Na}^{+}$and $\mathrm{K}^{+}$ions behaves differently because $\mathrm{Na}_{2} \mathrm{CO}_{3}$ and $\mathrm{K}_{2} \mathrm{CO}_{3}$ are soluble and may remain as ionic species in solution. In this case, the carbonation produces a less abrupt $\mathrm{pH}$ change and, although the final $\mathrm{pH}$ value just when the flux of $\mathrm{CO}_{2}$ stops in again around neutrality (only bicarbonates and dissolved $\mathrm{CO}_{2}$, are present), because of the well known equilibrium shown in figure 9 , the $\mathrm{pH}$ spontaneously evolues to a value of around 10.4 , that of the buffer carbonate - bicarbonate (9).

A simple extrapolation of these results to the real behaviour would conclude that an alkaline solution containing $\mathrm{Na}^{+}$and $\mathrm{K}^{+}$ions and completelly carbonated may have $\mathrm{pH}$ values of around 10.4 where the phenolphtalein indicator would have a clear red-purple colour. But all cements have alkalies in a higher or lower proportion and it has been observed in all carbonated concretes that the phenolphtalein indicator (colour variation from $\mathrm{pH}=8$ to 9.5) is colourless, thus $\mathrm{pH}$ is below 8. Therefore, either $\mathrm{Na}^{+}$and $\mathrm{K}^{+}$remain always as bicarbonates - which is not possible at the usual $\mathrm{CO}_{2}$ partial presures in the atmosphereor these ions "disappear" from the solution. One hypothesis is that they $\left(\mathrm{Na}^{+}\right.$and $\mathrm{K}^{+}$ions) are consumed by the amorphous silica (pozzolanic reaction) (10) produced by the action of the $\mathrm{CO}_{2}$ on the silicates (2) and, thus, only $\mathrm{H}_{2} \mathrm{O}$ with dissolved $\mathrm{CO}_{2}$ would be the final composition of the pore solution. Bicarbonates would be present only if the $\mathrm{CO}_{2}$ partial presure were high enough.

The interpretation given here as to accelerated carbonation and the equilibrium of $\mathrm{CO}_{3}=/ \mathrm{HCO}_{3} \cdots$ and the $\mathrm{pH}$ values involved is well known concerning natural and tap waters as is even the corrosive effect of these waters on the concrete itself. However the authors have never found it in the literature reviewed except (11) (12) and the "surprise" reported by Verbeck (13) when he considers "the effect of alkaly hydroxide concentration on the equilibrium $\mathrm{pH}$ values at different $\mathrm{CO}_{2}$ presures. The calculation shows that for a liquid phase containing $1 \mathrm{~N} \mathrm{KOH}$ the equilibrium at $\mathrm{CO}_{2}$ pressure of the natural air should be about 10.5. This presents a paradoxical situation where such a concrete remain alkaline to phenolphtalein whilst being 
paradójica ya que el hormigón permanecería alcalino frente a la fenolftaleína y estaría siendo carbonatado en la proporción que la presión parcial del $\mathrm{CO}_{2}$ en el aire permitiera. Algo de lixiviación debe ocurrir antes de que la fenolftaleína indique cierta carbonatación".

Cuando se produce una carbonatación natural el mecanismo es el mismo pero tan sólo se forman cantidades despreciables de bicarbonatos. Proporciones superiores pueden encontrarse en atmósferas industriales o contaminadas.

\section{Corrosión del acero}

Estudios (14) en disolución se han realizado en un intento por establecer el umbral de despasivación del acero cuando el valor del $\mathrm{pH}$ es inferior al de la disolución saturada de $\mathrm{Ca}(\mathrm{OH})_{2}$ y también se han publicado distintos valores de $\mathrm{pH}$ para este umbral no existiendo acuerdo entre los autores. Una posible explicación a esta divergencia puede encontrarse en la variedad de métodos que se han empleado para disminuir el $\mathrm{pH}$ por debajo de 12,6.

En cuanto a la relación existente entre carbonataciońn y corrosión, los autores establecieron una hipótesis previa (7) según la cual y de acuerdo con los resultados de Pourbaix (9), la despasivación tiene lugar a $\mathrm{pH} \simeq 8$ (ver figura 10 , ya publicada). Sin embargo, persistían algunas incógnitas en base a la desaireación provocada por el empleo de $\mathrm{CO}_{2}$ puro en el proceso de carbonatación. Los presentes resultados en los que se emplea simplemente aire para

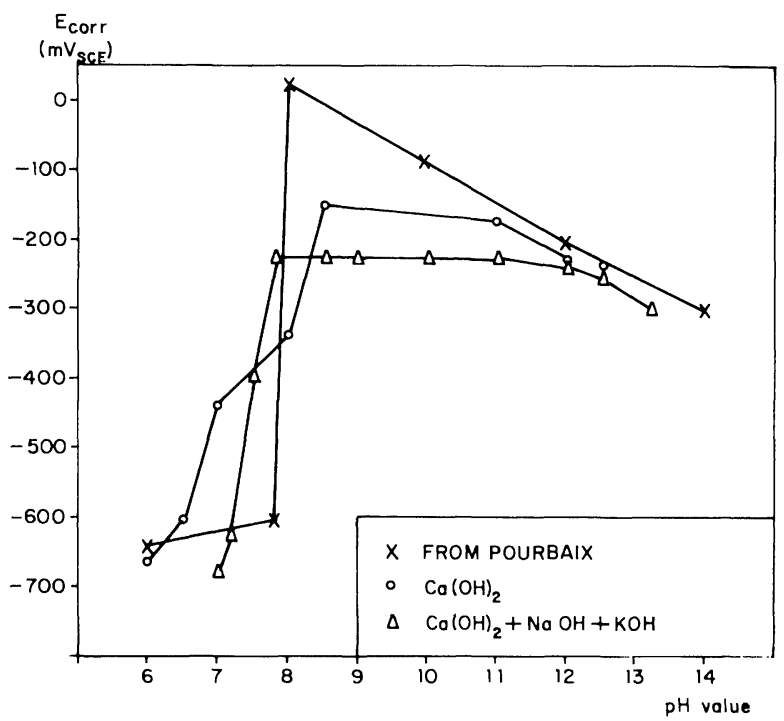

as carbonated as the partial pressure of $\mathrm{CO}_{2}$ in air will allow. Some leaching must occur before the phenolphtalein will indicates a carbonation edge".

When natural carbonation is produces, the mechanism is the same but only negligible amounts of bicarbonates are produced. Higher amounts may be found in industrial or contaminated atmospheres.

\section{Corrosion of steel}

Studies (14) were carried out in solution in an attempt to stablish the threshold at which steel is depassivated when its $\mathrm{pH}$ is lower thon of the saturated solution of $\mathrm{Ca}(\mathrm{OH})_{2}$. No agreement was reached and many $\mathrm{pH}$ values have been published as the limit (14). One possible explanation of this disagreement is the variety of methods used to decrease the pH from 12.6.

Concerning corrosion and carbonation, a previous hypothesis (7) was stated (see figure 10 already published) to the effect that depassivation occurs at $\mathrm{pH} \simeq 8$ as Pourbaix has described many years ago (9). However some doubts remained over deaeration using pure $\mathrm{CO}_{2}$ for carbonation. The present results using simply air for carbonating confirm this previous explanation. They also support Pourbaix's results which show that the passive layers remains in spite of the lowering of the

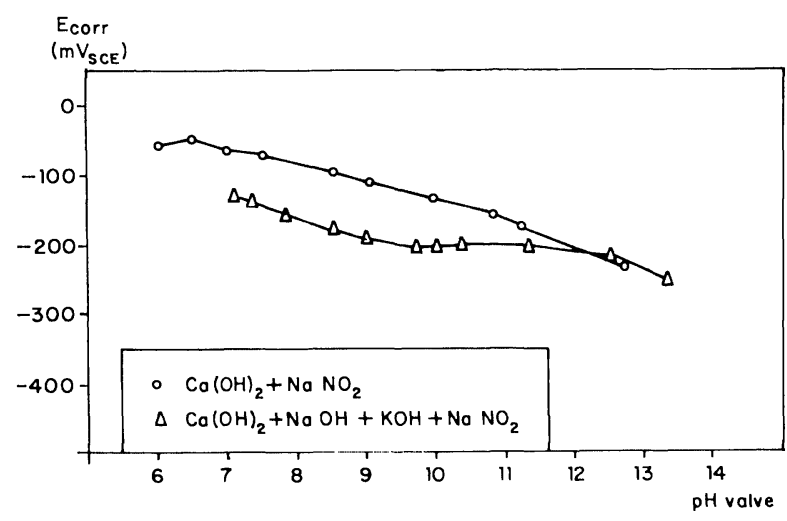

Fig. 10.-Dependence of the $E_{c o r r}$ on the $\mathrm{pH}$ values for the solutions whose evolution during carbonation was presented in figures 2 and 7. 
carbonatar las disoluciones, confirman aquella explicación previa. También apoyan los resultados de Pourbaix que indican que las capas pasivas permanecen a pesar del descenso de $\mathrm{pH}$ cuando $\mathrm{NaNO}_{2}$ (inhibidor oxidante) está presente. Los cambios en el potencial de corrosión son debidos principalmente a la dependencia de la ley de Nersnt y la intensidad de corrosión a la del valor del $\mathrm{pH}$, tal y como ya ha sido indicado en anteriores publicaciones (3).

\section{CONCLUSIONES}

1. a) La carbonatación acelerada (elevada presión parcial de $\mathrm{CO}_{2}$ ) produce una desaireación de la disolución que tan solo influye en la velocidad de corrosión y no en el mecanismo de despasivación.

2. $\left.{ }^{a}\right)$ La carbonatación acelerada durante el flujo de $\mathrm{CO}_{2}$ produce elevadas cantidades de bicarbonatos que modifican los valores de $\mathrm{pH}$. La carbonatación expontánea produciría cantidades despreciables de bicarbonatos.

3. $\left.{ }^{a}\right)$ En presencia de iones $\mathrm{Na}^{-}$y $\mathrm{K}^{+}$el valor final del $\mathrm{pH}$ de una disolución que simula la fase acuosa encerrada en los poros de hormigón completamente carbonatada es aproximadamente 10,4 , en las condiciones ensayadas.

4. ) La capa de pasivación desaparece del acero a $\mathrm{pH} \simeq 8$, tal y como Pourbaix estableció hace años. En presencia de $\mathrm{NaNO}_{2}$, la capa de pasivación permanece aún cuando se produzca un descenso del valor del $\mathrm{pH}$.
$\mathrm{pH}$ value, when $\mathrm{NaNO}_{2}$ (oxydant inhibitor) is present. Changes in the corrosion potential are due mainly to Nersnt's law and corrosion intensity depends on the $\mathrm{pH}$ value, as previously reported (3)

\section{CONCLUSIONS}

1. $\left.{ }^{2}\right)$ Acelerated carbonation (high partial presure of $\mathrm{CO}_{2}$ ) induces a deaeration of the solution, but this deaeration only influences the corrosion rate and not the mechanism of depassivation.

2. $\left.{ }^{2}\right)$ Accelerated carbonation during the flux of $\mathrm{CO}_{2}$ gas produces high amounts of bicarbonates which modify the $\mathrm{pH}$ values. Spontaneous carbonation should produces negligible amount of bicarbonates.

3. $\left.{ }^{2}\right)$ When $\mathrm{Na}^{+}$and $\mathrm{K}^{+}$are present the final $\mathrm{pH}$ value of a completely carbonated solution simulating the pore concrete solution is around $\mathrm{pH}=10.4$, under test conditions.

4. $\left.{ }^{2}\right)$ The passive layer disappears from steel at $p H \simeq 8$, as Pourbaix has stated many years ago. When $\mathrm{NaNO}_{2}$ is present, the passive layer remains in spite of the lowering of the $\mathrm{pH}$ value.

\section{BIBLIOGRAFIA}

(1) H. HAMADA: Proceedings of the 5th Int. Symposium on the Chemistry of Cement. Tokyo (1968) - vol. III. 343.

(2) D. GASPAR, M. MUÑOZ, T. VAZQUEZ: Materiales de Construcción, núm. 168 (1977).

(3) J. A. GONZALEZ, S. ALGABA, C. ANDRADE: British Corrosion Journal (1980), 15, 3, 135.

(4) M. VENUAT: Materiaux et Construction (1978) 11, 142.

(5) H. G. SMOLCZYK: Rilem Symposium on Carbonation of Concrete. C.C. As. April (1976) Wexham Springs. Theme 3.2.

(6) P. SCHIESSEL: Betonwerk + Fertigteil Technik (1975), 12, 594

(7) J. A. GONZALEZ, C. ALONSO, C. ANDRADE: "Corrosion of reinforcements in concrete construction" -Chapter 11The Society of Chemical Industry - Ellis Horwood Ltd- (1983), 159.

(8) M. STERN, A.L. GEARY, J.: Electrochem. Soc. (1957) 104, 56.

(9) M. POURBAIX: "Lectures on Electhochemical Corrosion" - Plenum Press, New York and London, (1973).

(10) C. L. PAGE, $\varnothing$ VENNESLAND: Materiaux et Construction (1983) (16), 19.

(11) N. ASCHAN: Nordisk Betong (1963) 3, 275.

(12) D. BONNET M. RUBAUD: Cahiers n.॰ 1371 du CSTB n.॰ 168 (1976).

(13) G. J. VERBECK: Bulletin P.C.A. n.० 87 - February (1958).

(14) V. K. GOUDA: British Corrosion Journal (1970) 5, 198. 